\title{
THE BROKEN COMPASS: THE REQUIREMENT THAT A CASE ARISE "DIRECTLY" UNDER FEDERAL LAW *
}

\section{WIILIAM CoHen $\dagger$}

“. . . the courts have formulated the distinction between controversies that are basic and those that are collateral, between disputes that are necessary and those that are merely possible. We shall be lost in a maze if we put that compass by." 1

"This is not logic. It is practical politics." 2

Chief Justice Marshall wrote in the case of Osborn v. Bank of the United States ${ }^{3}$ that a case arises under federal law when a federal question "forms an ingredient of the original cause." 4 Ever since, defining the "case arising under federal law" jurisdiction of the inferior federal courts has been a puzzle to judge ${ }^{5}$ and scholar $^{6}$ alike. Marshall held that the statute authorizing the Bank to sue and be sued in federal courts was constitutional since all suits by the Bank of the United States arose under federal law. No matter what the nature of the claim sought to be enforced by the Bank, the capacity of the Bank to sue and be sued was a potential question of federal law in each case. ${ }^{7}$ The problems which continue to plague definition of federal question jurisdiction in the federal trial courts were described

* Professor Paul J. Mishkin has been of considerable assistance to me in straightening out my thinking about the problems discussed here. The usual disclaimerthat he is not responsible for my errors or lapses-is appropriate throughout, but particularly so where he has failed to convert me or I have failed to persuade him.

$\dagger$ Professor of Law, University of California, Los Angeles. B.A. 1953, LL.B.

1956, University of California, Los Angeles. Member, California Bar.

1 Cardozo, J., in Gully v. First Natil Bank, 299 U.S. 109, 118 (1936).

2 Andrews, J., in Palsgraf v. Long Island R.R., 248 N.Y. 339, 352, 162 N.E. 99. 103 (1928) (dissenting opinion).

322 U.S. (9 Wheat.) 738 (1824).

$4 I d$. at 822 .

5 Few subjects . . . are involved in greater perplexity . . . Many criteria have been laid down for determining when a suit arises under federal law. They can be classified but they cannot be harmonized.

Amidon, J., in McGoon v. Northern Pac. Ry., 204 Fed. 998, 1000 (D.N.D. 1913). 6 Neither in theory nor in practice can a self-contradictory dogma decide a case. To be sure, the judicial process does not cease to function because of either vagueness or contradiction in the doctrines it proposes to apply. Its modus operandi is just the more hidden and mysterious.

Chadbourn \& Levin, Original Jurisdiction of Federal Questions, 90 U. PA. L. REv. 639, 671 (1942) [hereinafter cited as Chadbourn \& Levin].

$7 \mathrm{It}$ is not relevant that the question had been authoritatively decided. "The right to sue, if decided once, is decided forever; but the power of Congress was 
by Justice Johnson's dissent. 8 Where suits were brought originally in federal courts, jurisdiction founded upon the federal nature of the questions involved was founded "on a mere hypothesis." 9 Before the issue was joined and the cause tried, it was not possible to determine whether questions of federal law would, in fact, be in issue. If the federal trial court had jurisdiction because questions of federal law might arise in the litigation, "jurisdiction . . . over almost every possible case, might be transferred to the Courts of the United States." 10

Of course, at the time of the Osborn opinion, federal courts had not been given jurisdiction generally over cases arising under federal law. It was not until 1875 that Congress chose to vest such jurisdiction in the federal trial courts in the language of the constitutional grant. ${ }^{11}$ To have interpreted the statutory grant of jurisdiction to extend the jurisdiction of the federal trial courts to all cases where issues of federal law might possibly be in issue was impractical. Such an interpretation would make those courts substantially courts of general jurisdiction, since large numbers of law suits could be said to depend potentially on relevant issues of federal law. For this reason, the Osborn test has been abandoned as the standard for defining the scope of the general grant of federal question jurisdiction. ${ }^{12}$ And, for the same reason, the statutory grant has been conceded to vest in the federal courts less than the scope of federal question jurisdiction which Congress might vest. ${ }^{13}$

exercised antecedently to the first decision on that right, and if it was constitutional then, it cannot cease to be so, because the particular question is decided." 22 U.S. (9 Wheat.) at 824. There were actual federal questions, of course, in the Osborn case. In a companion case, however, the Court sustained jurisdiction in a suit by the bank as bearer of negotiable notes. United States v. Planters' Bank, 22 U.S. (9 Wheat.) 904 (1824).

$8 I d$. at 871 .

${ }^{9} \mathrm{Id}$. at 884 .

10 Id. at 875 .

11 Act of March 3, 1875, §1, 18 Stat. 470.

12 Over the dissent of Chief Justice Waite, who argued that Congress did not intend to adopt the broad meaning of the Osborm decision, the Court held that federally chartered corporations could remove suits against them as "suits arising under the laws of the United States." Pacific Railroad Removal Cases, 115 U.S. 1 (1885). But, on the same day, the Court rejected the substance of Marshall's analysis in holding that a suit upon a federal judgment did not arise under federal law. Provident Sav. Life Assur. Soc'y v. Ford, 114 U.S. 635 (1885). Congress has since provided specifically that federal incorporation is not a basis for federal jurisdiction, 28 U.S.C. $\S 1349$ (1964). The elimination of the provision for removal by plaintiffs, Act of March 3, 1887, 24 Stat. 552, corrected by Act of August 13, 1888, 25 Stat. 433, was held to preclude removal by defendant on the basis of a federal defense. Tennessee v. Union \& Planters' Bank, 152 U.S. 454 (1894).

13 Romero v. International Terminal Operating Co., 358 U.S. 354, 379-80 (1959); Gully v. First Nat'l Bank, 299 U.S. 109, 113 (1936) ; Textile Workers Union v. Lincoln Mills, 353 U.S. 448, 470 (1957) (dissenting opinion). See Mishkin, The Federal "Question" in the District Courts, 53 ColuMr. L. REv. 157, 160-63 (1953) [hereinafter cited as Mishkin]. Of course, the broad language of the statute, com- 
Rejecting potential federal question, however, as a test of general federal question jurisdiction does not supply an appropriate standard for defining that jurisdiction. The test suggested by Justice Johnson in his dissent in the Osborn case is likewise inappropriate. Justice Johnson believed that the jurisdiction must depend upon questions of federal law actually involved in litigation. Under this test, no case could be said to arise under federal law until the issues between the parties had been determined. ${ }^{14}$ For Justice Johnson, this proved that federal question jurisdiction could not be exercised in an original form-that it could be vested in the federal courts only upon removal or appeal from the state courts. ${ }^{15}$ Since 1875 , the problem has been to chart a safe course between the Scylla of "potential federal question" and the Charybdis of "actual federal question," in order to define jurisdiction in cases arising under federal law.

Over 90 years of litigation have made some things clear. First, a case may arise under federal law although no issue of federal law is in dispute. ${ }^{16}$ Thus, for example, there is jurisdiction in a suit to recover damages for infringement of a patent although only issues of fact, such as the identity of the infringer or proof of the amount of damage, are involved. ${ }^{17}$ It is not anomalous that federal courts should exercise jurisdiction to enforce federal rights in cases where only issues of fact are put in issue. ${ }^{18}$ Congress has not invested the

bined with the broad statement of Senator Carpenter, who was in charge of the bill, 2 Cong. REC. 4986-87 (1874), argue for the interpretation that Congress intended to give the federal trial courts all the judicial power specified in Article 3 of the Constitution. Forrester, The Nature of a "Federal Question," 16 Tulane L. Rev. 362, 374-76 (1942).

Professors Chadbourn and Levin have argued that Congress intended to provide relief from litigation technically within the limits of the Osborm rationale in section 5 of the Act of 1875, 18 Stat. 470,472, which required dismissal or remand if it appeared at any time "such suit does not really and substantially involve a dispute or controversy within the jurisdiction of said circuit court." Chadbourn \& Levin 649-50. See Robinson v. Anderson, 121 U.S. 522, 524 (1887). The provision was eliminated in the 1948 revision of the Judicial Code as "unnecessary." Revisers" Note following 28 U.S.C. $\$ 1359$ (1964).

14 "[U]ntil the plaintiff can control the defendant in his pleadings, I see no practical mode of determining when the case does occur, otherwise than by permitting the cause to advance until the case for which the Constitution provides shall actually arise." 22 U.S. (9 Wheat.) at 889.

15 "[T] he peculiar nature of this jurisdiction is such, as to render it impossible to exercise in a strictly original form ...." Ibid.

16 See McGoon v. Northern Pac. Ry., 204 Fed. 998, 1001 (D.N.D. 1913) ; Chadbourn \& Levin 660-61; Mishkin 170-71; Note, 37 CoLUM. L. REv. 1402, 1403.

17 The Fair v. Kohler Die \& Specialty Co., 228 U.S. 22 (1913). Moreover, so long as the plaintiff's claim is strbstantial, jurisdiction is not ousted by the plaintiff's failure to state a cause of action. Id. at 25 . So long as the claim is substantial, jurisdiction exists even if a claimed federal right proves to be non-existent. Bell v. Hood, 327 U.S. 678 (1946).

18 The confusion of doctrine in this area results, at least in part, from the continued repetition of meaningless or even misleading phrases. An example is the repeated statement that the law suit "really and substantially involves a dispute or controversy respecting the validity, construction, or effect of such a law . . . ." 
inferior federal courts with general jurisdiction to hear cases arising under federal law merely because these courts are presumed to be more expert than the state courts in the interpretation of questions of federal law. The inferior federal courts can, in addition, be expected to be more sympathetic to the enforcement of federal rights claimed by the plaintiff. Potential antagonism in the state courts to the enforcement of the plaintiff's federal right may adversely color findings of fact as well as rulings on issues of law. It is desirable that a federal forum be available for trial of factual issues upon which the enforcement of federal rights may be based. ${ }^{19}$

It is equally clear that a case does not arise under federal law where the plaintiff asserts a claim founded solely upon state law and federal issues enter the case by way of defense. ${ }^{20}$ Louisville \& Nashville R.R. v. Mottley ${ }^{21}$ presents a striking illustration of the rule requiring that the federal question be "well pleaded" in the plaintiff's complaint. Mr. and Mrs. Mottley had been injured in a railroad accident in 1871 and given life-time free passes on the railroad in consideration of release of their damage claims. Congress enacted a statute forbidding the giving of free rides or free transportation. The railroad thereafter refused to renew the Mottleys' passes, claiming that to do so would violate the statute. The Mottleys brought suit in a federal court seeking specific performance of the railroad's promise. Their complaint alleged that the railroad refused to comply with its agreement solely because of the statute, and that the statute properly construed did not forbid the issuance of passes to them. Further, their complaint maintained that if the statute were construed to permit the revocation of such passes it constituted a taking of property in violation of the Fifth Amendment. The Court held that the case did not arise under federal law. In a complaint for specific performance of a contract, it was necessary only to allege the contract and its

Shulthis v. McDougal, 225 U.S. 561, 569 (1912). The statement results from an uncritical adoption of the standard for defining the scope of the Supreme Court's appellate jurisdiction over state courts, where it is both possible and sensible to limit jurisdiction to review of those cases where federal law issues were "really and substantially" dispositive of the litigation. See Cohens v. Virginia, 19 U.S. (6 Wheat.) 264,379 (1821); Mishkin at 170 . With the exception of Robinson v. Anderson, 121 U.S. 522, 524 (1887), the Court has ignored this supposed requirement while paying it lip service. See, e.g., Justice Cardozo's opinion in Gully v. First Nat'1 Bank, 299 U.S. 109, 113 (1936). But cf., Boston \& Montana Consol. Copper \& Silver Mining Co. v. Montana Ore Purchasing Co., 188 U.S. 632, 643 (1903). For historical development of the various mutually contradictory verbal devices in this area, see Chadbourn \& Levin 666-71; see also id. at 649-63.

19 Forrester, Federal Question Jurisdiction and Section 5, 18 TUL. L. REv. 263, 287 (1943) ; Mishkin 170-76.

20 See Tennessee v. Union \& Planters' Bank, 152 U.S. 454 (1894); Metcalf v. Watertown, 128 U.S. 586 (1888); cf., Skelly Oil Co. v. Phillips Petroleum Co., 339 U.S. 667 (1950).

21211 U.S. 149 (1908). 
breach. The allegations concerning the statute, its construction, and its claimed unconstitutionality were appropriately matters to be raised in the defendant's answer and the plaintiff's reply. To found federal jurisdiction, it was not only necessary to have federal questions appear in the plaintiff's complaint, but also that federal questions so presented be properly alleged as a matter of good pleading. ${ }^{22}$

The result in the Mottley case is startling, since it is apparent that only issues of federal law were in dispute. ${ }^{23}$ Requiring such litigation to be brought initially in state court is not easily explained. ${ }^{24}$ The "well-pleaded" rule has the advantage of providing a rule of thumb to deny access to federal courts to a large number of cases where potential federal issues lurk. Moreover, the rule can be defended as a pragmatic rule of necessity which permits the determination of jurisdiction when the complaint is filed, without awaiting the defendant's pleading. ${ }^{25}$ Like any rule of thumb, however, it operates blindly to preclude original federal jurisdiction in cases where, as a matter of sound policy, the parties ought to be permitted to choose a federal forum. ${ }^{26}$

22 The Court quoted the following language of Mr. Justice Peckham, in Boston \& Montana Consol. Copper \& Silver Mining Co. v. Montana Ore Purchasing Co., 188 U.S. 632,639 (1903) :

It would be wholly unnecessary and improper in order to prove complainant's cause of action to go into any matters of defense which the defendants might possibly set up, and then attempt to reply to such defense, and thus, if possible, to show that a Federal question might or probably would arise in the course of the trial of the case. To allege such defense and then make an answer to it before the defendant has the opportunity to itself plead or prove its own defense is inconsistent with any known rule of pleading so far as we are aware, and is improper.

Id. at 153 .

23 The legal issues which the Mottleys had attempted to present by their anticipatory pleading were subsequently presented to the United States Supreme Court on appeal from the later state court decision. Louisville \& N.R.R. v. Mottley, 219 U.S. 467 (1911). The state courts granted specific performance, but the Supreme Court reversed, upholding the railroad's federal defense.

24 It may be, that as long as ultimate Supreme Court review is available, occasional cases, like the Mottley case, which require litigation of federal defenses in the state courts, are not as troublesome as they might be. The availability of discretionary review on certiorari, 28 U.S.C. $\$ 1257(3)$ (1964), is, of course, not a fair substitute for $\mathrm{jurisdiction}$ as of right in the trial court, if it is assumed that it is important to give parties access to federal courts for trial of federal law issues.

25 It is not a rule of necessity in the sense that alternative solutions are impossible. Special allegations of federal question jurisdiction in the complaint might have been permitted as are special allegations of diversity jurisdiction. See Mishkin at 164 . As noted, sispra note 13, Professors Chadbourn and Levin have argued that the Act of 1875 was intended to permit the denial of jurisdiction after all the pleadings were submitted. Whatever the practical arguments for and against permitting the jurisdictional question to remain in abeyance pending the filing of responsive pleadings, this solution now seems foreclosed by the repeal of the statute upon which the argument was based. See note 13 supra. Of course, these pragmatic considerations cannot explain why a defendant is not permitted to remove a case to federal court on the basis of a federal defense. Wechsler, Federal Jurisdiction and the Revision of the Judicial Code, 13 LAw \& CoNTEMP. PRoB. 216, 233-34 (1948).

26 Most of the inexplicable results in relegating litigation of federal issues to state courts stems from the requirement that jurisdiction be determined on the face 
The requirement that matters of federal law be "well-pleaded" in the complaint could not in and of itself provide a rationale for denying jurisdiction over all litigation which threatened to flood the federal courts when Congress generally authorized the assumption of jurisdiction in cases arising under federal law. In his dissent in the Osborn case, Justice Johnson warned, prophetically, that "there is not a tract of land in the United States, acquired under laws of the United States, whatever be the number of mesne transfers that it may have undergone, over which the jurisdiction of the Courts of the United States might not be extended . . . ." 27 After 1875, litigation concerning the title to Western lands threatened to engulf federal courts. Suits in ejectment could be dismissed readily under the "well-pleaded" rule. Although plaintiff's title may have been recently or remotely derived from a federal source, a complaint in ejectment need only allege the plaintiff's prior right to possession. As a matter of common law pleading, the claim that plaintiff's title was superior to that of the defendant would be raised in reply to the defendant's answer. ${ }^{28}$ In suits to quiet title, however, plaintiff could appropriately plead the source of his title in his complaint. ${ }^{29}$ Unless the federal courts, whose resources were severely strained, were to be available in all quiet title actions involving Western land, a doctrinal device had to be developed to remove such cases from federal jurisdiction..$^{30}$

There has been much written about federal question jurisdiction. It is not the function of this article to explore, at length, those doctrinal roads which have been so well mapped by others. ${ }^{31}$ I propose

of the complaint without reference to the issues which separate the parties in the particular lawsuit. See Chadbourn \& Levin 649-63. Much of the rigidity introduced by the "well-pleaded" rule could be avoided by rejecting the rationale of Skelly Oil Co. v. Phillips Petroleum Co., 339 U.S. 667 (1950), which requires that the pleadings in a declaratory judgment action be judged as if the plaintiff had brought a common law coercive action. Another, more effective solution, would be to enlarge defendant's opportunity to remove on the basis of a federal defense. See text accompanying notes 108-09 infra.

2722 U.S. ( 9 Wheat.) at 875.

28 See Joy v. St. Louis, 201 U.S. 332 (1906).

29 See Shulthis v. McDougal, 225 U.S. 561 (1912); Marshall v. Desert Properties Co., 103 F.2d 551 (9th Cir.), cert. denied, 308 U.S. 563 (1939).

30 A suit to enforce a right which takes its origin in the laws of the United States is not necessarily, or for that reason alone, one arising under those laws, for a suit does not so arise unless it really and substantially involves a dispute or controversy respecting the validity, construction or effect of such a law, upon the determination of which the result depends. This is especially so of a suit involving rights to land acquired under a law of the United States. If it were not, every suit to establish title to land in the central and western States would so arise, as all titles in those States are traceable back to those laws.

Shulthis v. McDougal, supra note 29 , at $569-70$.

311 Barron and Holtzoff, Federal Practice and Procenure 120-30 (Wright ed. 1960); Dobie, Federal Procedure 163-83 (1928); Hart and Wechsler, The 
to focus upon that doctrinal requirement last mentioned-beyond the requirement that a federal ingredient be "well-pleaded" in the complaint-which seeks to limit the scope of the statutory grant of federal question jurisdiction. For convenience, that requirement can be described as requiring that a claim arise "directly" under federal law. ${ }^{32}$ It is my purpose to explore the history of the development of and to ascertain whether any meaning can be ascribed to this ephemeral rule of federal question jurisdiction, in order to explain the results reached by the Court.

\section{The Law That Creates the Cause of Action}

The early decisions construing the Act of 1875 , which gave jurisdiction to the federal trial courts in cases arising under federal law, contain conflicting and confused language from which contradictory theories can be drawn. ${ }^{33}$ However, one line of decisions is entitled to separate consideration-that which attempted to define jurisdiction according to whether federal or state law created the plaintiff's cause of action. The earliest clear example of this rationale is the case of Feibelman $v$. Packard. ${ }^{34}$ While the rationale of this case has often been ignored, perhaps because of the unilluminating opinion of Mr. Justice Matthews, the Court upheld jurisdiction because federal law had given plaintiff his cause of action, although no questions of federal law were actually in dispute. Plaintiff had brought suit against a United States marshal and the sureties on the marshal's bond to recover damages for alleged unlawful taking of property pursuant to a federal court warrant. Removal to federal court was upheld on the ground that "the nature of the plaintiff's cause of action" demonstrated that the case arose under federal law. The Court distinguished a suit against the marshal for trespass from this suit to recover damages on the bond. While the issues to be litigated might be identical, in the latter case federal statutes expressly required the bond and provided for suit thereon.

Mr. Justice Holmes stated the theory with more clarity thirty years later. In The Fair $v$. Kohler Die \& Specialty Co., ${ }^{35}$ plaintiff

Federal Courts and the Federar System 727-809 (1953) ; 1 Moore, Federal PracRICE T 0.60[8.-3] (2d ed. 1964); WRIGHT, FEDERAL CourTs 48-59 (1963) ; Bergman, Reappraisal of Federal Question Jurisdiction, 46 Mrcr. L. REv. 17 (1947); Chadbourn \& Levin; Forrester, Federal Question Jurisdiction and Section 5, 18 Tulane L. Rev. 263 (1943) ; Forrester, The Nature of a "Federal Question," 16 TUlane L. REv. 362 (1942); Fraser, Some Problems in Federal Question Jurisdiction, 49 MrCH. L. Rev. 73 (1950); London, "Federal Question" Jurisdiction-A Snare and a Delusion, 57 MICH. L. Rev. 835 (1959) ; Mishikin.

32 Gully v. First Nat' Bank, 299 U.S. 109, 117-18 (1936) ; Mishkin 165, 168.

33 The doctrinal confusion of the early cases has been admirably chronicled elsewhere. See Chadbourn \& Levin.

34109 U.S. 421 (1883).

35228 U.S. 22 (1913). 
sought to enjoin the resale of plaintiff's patented devices at less than the stipulated price. The defense claim was that the patent law did not permit the manufacturer-patent-holder to control resale prices. The Court held that the defense contention, even if true, did not oust the court of jurisdiction. Mr. Justice Holmes stated:

[G]ood or bad, the cause of action alleged is a cause of action under the laws of the United States.

Of course the party who brings a suit is master to decide what law he will rely upon and therefore does determine whether he will bring a "suit arising under" the patent or other law of the United States by his declaration or bill. ${ }^{36}$

The Fair did not involve the problem of the mixed claim of federal and state law, but the problem of distinguishing a "substantial" federal claim from one so insubstantial as not to provide a basis for federal question jurisdiction. Holmes later attempted to regularize "the law creating the cause of action" as an all-purpose test of federal question jurisdiction for those cases where the plaintiff's claim combined elements of federal and state law. In his opinion for the Court in American Well Works Co. v. Lane \& Bowler Co., ${ }^{37}$ he held there was no jurisdiction in a removed case because plaintiff's cause of action derived from state law. Yet, in all probability, the case turned solely on issues of federal law. Plaintiff alleged that defendant had slandered title to plaintiff's pump by falsely stating it infringed defendant's patent. It should be noted, preliminarily, that the "wellpleaded" rule will not, alone, explain the decision that the case does not arise under federal law. Apparently, in cases involving trade libel, as distinguished from cases involving personal defamation, falsity of the defendant's statements must be alleged in the complaint as part of the plaintiff's cause of action. ${ }^{38}$ Allegations of the falsity of defendant's statements then raise the issue of the scope and validity of the defendant's patent rights. In any event, Mr. Justice Holmes' opinion for the Court did not rest on the contention that truth of the defendant's claim of infringement was an issue to be raised affirmatively in the answer. Rather, his reasoning was that if false claims of patent infringement are actionable, they are actionable because state law provides a cause of action for trade libel. ${ }^{39}$ Establishing a particular position of federal law was no more, in other words, than a "condition" of recovery.

$36 \mathrm{Id}$. at 25 .

37241 U.S. 257 (1916).

38 PROSSER, TORTS 943 ( 3 d ed. 1964).

39 The same reasoning would explain the rule that a suit upon a contract to pay royalties to the patent-holder does not arise under the patent laws. Albright $v$. Teas, 106 U.S. 613 (1882). 
A suit arises under the law that creates the cause of action. The fact that the justification may involve the validity and infringement of a patent is no more material to the question under what law the suit is brought than it would be in an action of contract. . . . The state is master of the whole matter, and if it saw fit to do away with actions of this type altogether, no one, we imagine, would suppose that they still could be maintained under the patent laws of the United States. ${ }^{40}$

Holmes' test has, at first blush, strong appeal as a neutral, analytical tool to solve the puzzle of marking the line of original federal question jurisdiction in cases involving mixed elements of state and federal law. It has severe limitations, however, undermining its ability either to explain past decisions or chart the course for the future. First is the problem of applying the test. Holmes' reasoning in American Well Works was that the plaintiff's cause of action arose under state law because he could not recover unless he could demonstrate that state law gave him a right of action for trade libel-"the state is master of the whole matter." The difficulty is that this brand of "but-for" reasoning could easily have led to the opposite conclusion if approached from the other end. In other words, plaintiff could not recover unless he could demonstrate the invalidity or limited scope of the defendant's patent-issues as to which federal law "is master of the whole matter." Unless Holmes meant to take the untenable position that no case involving mixed elements of state and federal law arises under federal law, "but-for" standards do not determine whether the cause of action is federal or state. What appears to be a self-applying analytical standard breaks down because it fails to supply an analytical definition which will determine whether plaintiff's claim is a federal cause of action incorporating state law, or a state cause of action incorporating federal law. ${ }^{41}$

The leading case of Smith $v$. Kansas City Title \& Trust Co. ${ }^{42}$ is illustrative of the difficulty. A corporate shareholder sued to enjoin the corporation from investing in farm loan bonds, issued by Federal Land Banks or Joint-Stock Land Banks under authority of the Federal Farm Loan Act of 1916, on the ground that the Act was unconstitutional. The Court held that the case arose under federal law because the invalidity of the law was properly alleged in the complaint, and plaintiff's success depended upon establishing the construction of federal law propounded by the plaintiff. The Court had turned around

40241 U.S. at 260. (1953).

41 See Hart \& Wechsler, The Federal Courts and the Federal System 766 42255 U.S. 180 (1921). 
the "but-for" test of American Well Works to focus on the essentiality of the allegations of federal law. Holmes dissented, arguing that the suit was to establish breach of the corporate directors' stateimposed duty to properly invest corporate funds.

If the Missouri law authorizes or forbids the investment according to the determination of this Court upon a point under the Constitution or acts of Congress, still that point is material only because the Missouri law saw fit to make it so. The whole foundation of the duty is Missouri law, which at its sole will incorporated the other law as it might incorporate a document. The other law or document depends for its relevance and effect not on its own force but upon the law that took it up, so I repeat once more the cause of action arises wholly from the law of the State. ${ }^{43}$

Despite the fact that there was no serious claim that Missouri in fact permitted investment of corporate funds pursuant to unconstitutional federal laws, Holmes insisted that the cause of action arose under state law because plaintiff's standing to challenge the law could have been nullified by a hypothetically different state law. Again, unless Holmes is seriously arguing that no mixed state and federal claim arises under federal law, his test does not explain his contention that the plaintiff's cause of action in Smith is state rather than federal. If Holmes is right that the plaintiff's cause of action should be properly characterized as state-created, it must be for reasons he has failed to illuminate. Of course, the majority's reverse "but-for" reasoning leads to the conclusion that all mixed federal-state claims arise under federal law, and as a working standard of federal question jurisdiction has the vice of over-inclusiveness.

It may be rejoined that the distinction between cases where state law creates the cause of action and those where the law creating the cause of action is federal has enough substance that clear cases can be put on the extremes. Certainly, no distinction is valueless simply because borderline cases are hard to decide. In other words, the argument would run that clear cases can be put as to which everyone will agree; that federal law merely gives permission for the assertion of a state-created cause of action; or that a particular proposition of federal law is no more than a "condition" to assertion of a successful state cause of action. Such, for example, is the case of Skelly Oil Co. v. Phillips Petroleum Co., ${ }^{44}$ where contracts by gas suppliers provided that the contracts could be terminated if the purchaser failed to procure a certificate of public convenience and necessity from the Federal 
Power Commission before a certain date. The Commission issued a certificate, contingent upon certain conditions. A suit for declaratory judgment was brought for a determination whether the conditional certificate was a certificate within the meaning of the Natural Gas Act and the contracts. Here, it may be argued, the cause of action of any party to the contract was a state-law-based action on the contracts. Federal law was relevant only because the parties chose an event resting on federal law to measure the power of termination. ${ }^{45}$ So long as cases can be put where good lawyers will all agree that the cause of action is federal or state, the distinction then has enough meaning that it may be used as a tool for measuring federal jurisdiction. ${ }^{40}$

The argument just summarized bears a family resemblance to the argument put a legal generation ago by some procedure scholars who urged that the "cause of action" concept had enough meaning to be a useful analytical tool for solving such procedural problems as marking the permissible scope of joinder of parties and claims within a single lawsuit. ${ }^{47}$ While the corpse still twitches ${ }^{48}$ (perhaps because of some galvanic reflex action endemic to the law) that argument was put to rest by the convincing counter-demonstration that causes of action were defined by pragmatic factors generated by the particular controversy in the particular case. ${ }^{49}$ I suspect, whenever a concept cannot be defined except by circular reference to itself, that "easy cases" are more often explained by unstated pragmatic factors than by reference to any inherent reality in the concept itself. Are cases where "all lawyers will agree" that the plaintiff's cause of action is state-created sometimes the result of the fact that those same lawyers will agree, for unstated and unarticulated reasons, that the case does not "belong" in federal court? To the extent that this is true, the problem becomes that of discovering and articulating the relevant factors.

A second difficulty with the mystic belief that the cause of action concept had some inherent self-defining meaning stemmed from the fact that the concept had many uses. The question whether causes of action were single or multiple had such multifarious consequences as determining proper joinder at the outset of the lawsuit and determin-

45 Mishkin 183.

46 Professor Mishkin puts the analogous case where parties wager as to the next incumbent of a federal office. Id. at 184. For further discussion of this case see text accompanying notes 77-81 infra. 1947).

47 See articles cited in Clark, Code Pleading 132 n.149, 142 nn.177-79 (2d ed.

48 See Cohen, Problems in the Removal of a "Separate and Independent Claim or Canse of Action," 46 MinN. L. Rev. 1, 16-17 (1961).

49 See Clark, Code Pleading 137 (2d ed. 1947). 
ing the res judicata impact of the judgment obtained. Everyone might agree that there was a single cause of action because, unconsciously, this seemed to promote the proper result with reference to joinder questions. Uncritically applying this "hunch" definition of cause of action to a res judicata question might end in a result that flew in the teeth of the factors which ought to have controlled the decision. Is it possible that, in some cases where "all lawyers will agree" that the plaintiff's cause of action is state-created, the case, and all those like it, do "belong" in federal court? This difficulty is the exact converse of the first, but both may be present to some extent at the same time. In some cases, the conclusion that the cause of action is state-created may seem easy because the case does not "belong" in federal court; in some cases, an easy conclusion that the cause of action is statecreated may coincide by accident with the conclusion that the case does not "belong" in federal court; in some cases (and these may be the most difficult), an easy conclusion that the cause of action is state-created may, without good reason, conflict with the conclusion that the case does "belong" in federal court.

Smith v. Kansas City Title $\mathcal{E}$ Trust $\mathrm{Co}^{50}$ is again illustrative. In that case, the Court held that a corporate shareholder's suit to enjoin a corporation from participating in a federal program, on grounds that the federal act setting up the program was unconstitutional, arose under federal law. There is room for legitimate debate whether the shareholder should be given standing to challenge an act of Congress in a suit where the dangers of a collusive lawsuit loom large. ${ }^{51}$ The question of standing is the same, however, whether the suit proceeds in the state courts and then to the Supreme Court, or whether it is allowed to begin in a federal trial court. The question whether a suit arises under federal law is relevant only to the question whether litigation may commence in a federal court. Any doubts on the issue of standing should not be permitted to influence the question whether the suit may be begun in federal court, or whether it must find its way to the Supreme Court through state litigation. Passing the question of standing and focusing solely on the question whether the case arises under federal law, it is difficult to distinguish the situation in the Smith case from a suit by the corporation to enjoin enforcement of a coercive federal law on constitutional grounds. ${ }^{52}$ The

50255 U.S. 180 (1921).

51 See Ashwander v. T.V.A., 297 U.S. 288, 341, 349 (1936) (Brandeis, J., concurring). For a description of the manner in which the issues were framed in Carter v. Carter Coal Co., 298 U.S. 238 (1936), see Stern, The Commerce Clanse and the National Econony, 1933-1946, 59 HARv. L. REv. 645, 667-68 (1946).

52 By similar reasoning, a suit to declare a contract invalid under federal law should be appropriately within the jurisdiction, of a federal trial court. See Mishkin 181. 
latter suit would, concededly, arise under federal law. If it is conceded, arguendo, that Holmes correctly concluded that the Smith suit arose under state law, the constitutional questions in that case could be adjudicated in a federal court only on appeal from the state courts, while, in suits to enjoin the enforcement of coercive federal statutes, a federal trial court forum would be available. It would be difficult to give realistic reasons for such a distinction.

Another often-cited decision illustrates the other side of the coin-a situation where the Court's decision relegated to the state courts a cause of action which appears to have been created explicitly by an Act of Congress. Shoshone Mining Co. v. Rutter ${ }^{53}$ involved a thorough-going Congressional scheme for settling conflicting claims of miners. An application for issuance of a patent for a mining claim was to be filed in the General Land Office. If an adverse claim were then filed, the adverse claimant was required, within thirty days after filing his claim, to begin suit "in a court of competent jurisdiction," to determine his right to possession, and prosecute the action to judgment. The Commissioner of the General Land Office was directed to issue the patent in accordance with the judgment of the court. Finally, it was provided that right to possession was to be determined by "local customs or rules of miners in the several mining districts, so far as the same are applicable and not inconsistent with the laws of the United States." The Court held that the suit of an adverse claimant was not within the general grant of federal question jurisdiction. The Court's reasoning seemed to hark back to that of Justice Johnson's dissent in the Osborn case-denying jurisdiction because questions of federal law were not necessarily involved.

Inasmuch . . . as the "adverse suit" to determine the right of possession may not involve any question as to the construction or effect of the Constitution or laws of the United States, but may present simply a question of fact as to the time of discovery of the mineral, the location of the claim on the ground, or a determination of the meaning and effect of certain local rules and customs prescribed by the miners of the district, or the effect of state statutes, it would seem to follow that it is not one which necessarily arises under the Constitution and laws of the United States. ${ }^{54}$

The Shoshone case is indistinguishable from the case of the suit on the Marshal's bond ${ }^{55}$ under Holmes' test. In both cases, while most suits would center around issues of fact or of state law, the cause

53177 U.S. 505 (1900).

54 Id. at 509 .

55 Feibelman v. Packard, 109 U.S. 421 (1883). 
of action was expressly created by Act of Congress. Even if all lawyers will agree that the plaintiff's cause of action in Shoshone is federal (state law merely being incorporated by reference), it does not follow that the Court reached the "wrong" result. The Court was properly concerned with the volume of litigation which a contrary decision would have loosed upon federal trial courts overburdened by the expansion of jurisdiction caused by the Judiciary Act of 1875 . The Court, for pragmatic reasons, had refused to extend the jurisdiction to a large class of cases which would, in most instances, involve no clearly defined federal interest and no issue of federal law. The Court's failure-if one there was-lies in its failure to explain the result. The explanation would have been no more satisfactory had the Court tortured the statute to characterize the plaintiff's claim as one given by state rather than federal law. Inquiry into whether federal or state law confers the plaintiff's cause of action can be, at most, only a starting point for analysis.

\section{Arising "Directly" Under Federal Law-The Gully Case}

In Gully v. First National Bank ${ }^{56}$ a state tax collector sued a national bank in a state court to recover state taxes due. The taxes had been assessed against a predecessor national bank, whose debts had been contractually assumed by the defendant. The case was removed to federal court on the ground that the action arose under federal law since state taxation of national banks was permissible only because of a federal statute granting such permission. Thus, the state tax collector had to rely upon the statute in imposing the tax. Rejecting this argument, Mr. Justice Cardozo's opinion for the Court represents the Court's last attempt to deal comprehensively with the general statutory grant of federal question jurisdiction. Gully is not, unfortunately, a classic example of the Cardozo opinion-removing the underbrush of dead and dying contradictory prior decisions and leaving in its stead a clear path to follow for the future. The case, itself, could have been decided solely on the basis of the "well-pleaded" rule, on the ground that the tax collector's suit needed only to allege the state-law obligation to pay taxes. Federal law was relevant only because it had renounced a defense which the United States Constitution would otherwise have given the defendant; like the Mottley ${ }^{57}$ case, federal law, as a matter of pleading, provided a defense and a reply to the defense. Cardozo seems to rely squarely upon the "wellpleaded" rule, citing the Mottley decision, and stating that "a suit 
does not arise under a law renouncing a defense," any more than it arose in Mottley under a law creating a defense. ${ }^{58}$

Before reaching that point, however, Justice Cardozo had repeated and given new vitality to many of the unfortunate contradictory "tests" of the older cases. Such, for example, were the statements that "a genuine and present controversy, not merely a possible or conjectural one must exist," 59 and "a suit does not . . . arise unless it really and substantially involves a dispute or controversy respecting the validity, construction or effect of such a law, upon the determination of which the result depends." 60 These phrases had been uncritically transferred, in earlier cases, from the standard which appropriately governs the Supreme Court's appellate jurisdiction. There, given a case that has been tried and reviewed "by the highest court of a State in which a decision could be had," 61 the court appropriately limits its appellate jurisdiction to the decision of actual federal questions. While Cardozo perpetuates earlier confusion by continuing to recite an impossible actual federal question standard, he also relies heavily on Holmes' test of the law that creates the cause of action. The basis of the suit is the state-law obligation to pay taxes. "That there is a federal law permitting such taxation does not change the basis of the suit, which is still the statute of the state, though the federal law is evidence to prove the statute valid." 62 Had the opinion ended here, it would have been merely the last in a string of examples appropriately applying the "well-pleaded" rule to deny jurisdiction and continuing to recite, in addition, the meaningless or confusing "tests" of federal question jurisdiction from past cases. It is only in the last few paragraphs of the opinion that an attempt is made to strike new ground.

The most one can say is that a question of federal law is lurking in the background, just as farther in the background there lurks a question of constitutional law, the question of state power in our federal form of government. A dispute so doubtful and conjectural, so far removed from plain necessity, is unavailing to extinguish the jurisdiction of the states.

This Court has had occasion to point out how futile is the attempt to define a "cause of action" without reference to the context. . . . To define broadly and in the abstract "a case arising under the Constitution or laws of the United 
States" has hazards of a kindred order. What is needed is something of that common-sense accommodation of judgment to kaleidoscopic situations which characterizes the law in its treatment of problems of causation. One could carry the search for causes backward, almost without end. . . . Instead, there has been a selective process which picks the substantial causes out of the web and lays the other ones aside. As in problems of causation, so here in the search for underlying law. If we follow the ascent far enough, countless claims of right can be discovered to have their source or their operative limits in the provisions of a federal statute or in the Constitution itself with its circumambient restrictions upon legislative power. To set bounds to the pursuit, the courts have formulated the distinction between controversies that are basic and those that are collateral, between disputes that are necessary and those that are merely possible. We shall be lost in a maze if we put that compass by. ${ }^{63}$

Here are important new insights! Assuming a well-pleaded issue of federal law, the federal question jurisdiction of the federal trial courts is defined not by conceptual standards or self-applying talismanic phrases, but by "common-sense accommodation of judgment." There is room here for weighing countervailing pragmatic considerations in determining whether classes of cases should be eligible for initial trial in federal courts. But what are those factors, and how are they to be judged? Here, Cardozo's opinion lapses into an opaque mysticism which, thirty years later, is as impenetrable as when the opinion was written. What is the nature of the distinction between federal law controversies "that are basic and those that are collateral"? Can anyone chart a line between "disputes that are necessary and those that are merely possible"? If we have been given a compass to escape the maze, it is one with all directions pointing back into the maze. It is difficult to improve on the comment of Professors Chadbourn and Levin: "This is prose so beautiful that it seems almost profane to analyze it. . . How this magic can be performed still remains a mystery of the judicial process." 64

\section{Pragmatic Standards for a Pragmatic Problem}

The scope of the pragmatic problem of defining the limits of original federal question jurisdiction is easily stated. The bulk of federal civil litigation in the federal courts presents no jurisdictional problem. Routine federal question litigation arises under federal

63 Id. at $117-18$.

64 Chadbourn \& Levin 670-71. 
statutes which not only create federal causes of action but contain special grants of jurisdiction as well. ${ }^{65}$ It is the unusual, novel, atypical claim which presents the problem. A novel claim of mixed federal and state law ought to qualify as "arising under" federal law only if it exhibits those features which justify the need for federal trial court jurisdiction of federal question cases. A case that requires expertise in the construction of the federal law involved in the case, and a sympathetic forum for the trial of factual issues related to the existence of a claimed federal right, ought to fall within federal jurisdiction. On the other hand, a federal court should not be compelled to accept federal question jurisdiction over a class of suits which typically neither involves actual contested issues of federal law nor requires the protective jurisdiction of a sympathetic federal trial forum.

Judged by pragmatic considerations, most of the leading cases deciding whether a case "arises" under a well-pleaded federal law ingredient, appear, at least at this distance, properly decided. As already indicated, the two Supreme Court cases most difficult to square with "the law that creates the cause of action" standard are easily explained by pragmatic considerations. In stockholders' derivative suits presenting substantial federal constitutional objections to federal statutes, taken as a class, the federal constitutional issues are likely to be among the most significant in the litigation. In cases like Smith $v$. Kansas City Title \& Trust Co. ${ }^{B 6}$ it is certain that the federal constitutional issues will form the core of the litigation. Those issues require the same expert and sympathetic federal forum at the trial level as they would if presented in an injunction suit against a federal official. On the other hand, there is little reason to fear that the sustaining of jurisdiction in this class of litigation would add significantly to the workload of an overburdened federal judiciary. By contrast, the practical reasons for refusing jurisdiction in Shoshone Mining Co.v. Rutter ${ }^{67}$ were overwhelming. The congressional directive that controversies between rival claimants for mineral rights be decided by "local customs or rules of miners" meant that most of these lawsuits would turn on a combination of factual issues and interpretation of local law or custom, not requiring the expertise of a federal trial forum. There was no significant federal government interest in the choice between the rival claimants which would require the protective jurisdiction of a federal trial court. Finally, and most

65 The Senate Committee reporting on the 1958 amendments to the Judicial Code concluded that the only significant class of cases resting federal question jurisdiction on 28 U.S.C. $\$ 1331$ rather than a special jurisdictional statute were Jones Act cases and suits challenging the constitutionality of state statutes. S. REP. No. 1830, 85th Cong., $2 d$ Sess. (1958).

66225 U.S. 180 (1921).

67177 U.S. 505 (1900). 
important, accepting jurisdiction in Shoshone would have added significantly to the business of overburdened federal trial courts in the West.

It is not startling that these practical considerations precipitated the results in Smith and Shoshone. Nor is it unusual that the Court in the two cases applied contradictory analytical formulas to explain the results, rather than resting squarely on those factors which, no doubt, influenced the actual decisions. What is surprising is the continuing belief that there is, or should be, a single, all-purpose, neutral analytical concept which marks out federal question jurisdiction. A frank recognition of the pragmatic nature of the decisionmaking process would help throw light on the factors which actually induce decision. It would, moreover, reduce the danger that a judge would be beguiled by one of the numerous analytical tests into reaching an indefensible result.

A good example of an analytical formula producing the wrong result is American Well Works Co. v. Lane \& Bowler Co., ${ }^{68}$ where Justice Holmes' opinion for the Court rejected federal question jurisdiction in a suit by the alleged infringer of the defendant's patent. It will be recalled that Holmes reasoned that plaintiff's claim for slander of title was state-created. Congress had seen the need for a sympathetic and expert federal forum in patent cases as so significant that it had provided for exclusive jurisdiction by the district court in cases arising under the patent laws. The holder of a patent, in other words, was not given the option of vindicating his patent law claim in a state court. But, with the parties reversed, and the alleged infringer seeking judicial relief through the mechanism of a suit for slander of title, the doctrine of American $W$ ell $W$ orks produces an anomalous result. Not only can the alleged infringer compel the patent holder to litigate the validity and coverage of his patent in a state court, but neither party, in a suit by the alleged infringer, is allowed the choice of a federal forum. If there are sound pragmatic reasons which support this result, they are difficult to guess, unless the Court was concerned that the exclusive jurisdiction of federal courts in patent cases would unduly interfere with state court jurisdiction over state-law-based tort claims involving issues of federal patent law. ${ }^{69}$ It is significant that the Declaratory Judgment Act has been construed to create a federal claim by the alleged infringer for a declaratory judgment that the patent is invalid or not infringed. ${ }^{70}$

68241 U.S. 257 (1916).

69 Compare the rule that suits to enforce contracts concerning patent and copyright rights do not arise under federal law. Albright v. Teas, 106 U.S. 613 (1882).

70 E. Edelman \& Co. v. Triple-A Specialty Co., 88 F.2d 852 (7th Cir.), cert. denied, 300 U.S. 680 (1937); see Note, 62 Harv. L. REv. 787, 802-03 (1949). 
American Well Works remains the leading case for testing original federal question jurisdiction by the "law which creates the cause of action." But in the precise area of the decision-suits by alleged patent infringers-the practical unsoundness of its result has been largely overturned by interpretation of the Declaratory Judgment Act.

It may be objected that recognition of the pragmatic nature of the decision whether a claim arises directly under federal law will lead to an ad hoc, unpredictable, case-by-case decision of jurisdictional questions. It goes without saying that it is undesirable for jurisdictional rules to be uncertain. Particularly since objections to jurisdiction of the district court cannot be waived, ${ }^{\mathbf{7 1}}$ and since in many cases the lack of jurisdiction can even be asserted by the party who invoked federal jurisdiction, ${ }^{72}$ there should not be doubt about the threshold question of jurisdiction. The short answer may be that the maze of analytical standards used by the courts has not, as has been shown, produced consistent and predictable results in hard cases. It is also important to recall the context in which the difficult questions of whether a case arises directly under federal law are decided. There are no serious jurisdictional problems in the great bulk of civil cases which arise under federal law-they represent routine, repetitive litigation in which the jurisdictional issue has been settled by statute, case law, or both. ${ }^{73}$ Only the novel claim of mixed federal and state law presents the difficult question whether the case arises "directly" under federal law. The extent of jurisdictional uncertainty is, as it has been during most of the history of general federal question jurisdiction, of small import in the day-to-day work of the district courts.

More important, recognition of pragmatic factors and decisions based on them will lead to predictable jurisdictional standards. Thus, no matter how close the pragmatic judgment in a particular case, once made it is bound to decide more than just the case before the court. In other words, the process is not simply case-by-case decision making, with each case standing on its own bottom, but rather a process of clarifying jurisdictional uncertainty in classes of cases before the court. It is, of course, true that a case may be so unique that a jurisdictional decision has no impact on other cases. ${ }^{74}$ Very often, however, an authoritative decision of a novel problem of federal ques-

71 Mansfield, C. \& L. Mich. Ry. v. Swan, 111 U.S. 379 (1884).

72 E.g., American Fire \& Cas. Co. v. Finn, 341 U.S. 6 (1951). There are some devices which may soften the impact of the rule, as the subsequent court of appeals decision in this case shows. 207 F.2d 113 (5th Cir. 1953).

73 See note 65 sipra.

74 See, e.g., Rank v. Krug, 142 F. Supp. 1 (S.D. Cal. 1956) (complex water rights litigation); cf. In re Green River Drainage Area, 147 F. Supp. 127 (D. Utah 1956). 
tion jurisdiction settles the issue for a class of cases. Shoshone Mining Co. v. Rutter ${ }^{75}$ relegated a large group of miners' claims to the state courts. Until the Declaratory Judgment Act, American Well $W_{\text {orks }^{76}}$ placed suits by alleged patent infringers in the state courts. Smith $v$. Kansas City Title \& Trust Co. ${ }^{77}$ established a general jurisdictional rule for constitutional challenges through the mechanism of the stockholder's derivative suit. And so on.

Another case previously discussed illustrates the problem of deciding how large the jurisdictional class should be. In Skelly Oil Co. v. Phillips Petroleum Co., ${ }^{78}$ complex declaratory judgment litigation turned upon the interpretation of the phrase "certificate of public convenience and necessity" in a private contract. Among the questions to be decided was whether that term incorporated the meaning of the same term in the Natural Gas Act, and, if so, whether a document obtained by one of the parties from the Federal Power Commission was such a certificate. Mr. Justice Frankfurter's opinion for the Court explained that a federal district court lacked federal question jurisdiction on the basis of the "well-pleaded" rule. $\mathrm{He}$ reasoned that the issue of federal law involved would have been pleaded defensively in a traditional action for breach of contract, since the issue arose in the context of interpreting a condition subsequent giving the defendant power to terminate the contract. The Declaratory Judgment Act was held not to operate to confer jurisdiction to decide issues of federal law which would be pleaded defensively in a conventional lawsuit.

Professor Mishkin has persuasively criticized the Court's analysis in Skelly. ${ }^{79}$ Not only is it artificial and complex to judge the pleadings in a declaratory judgment action as if the plaintiff had brought a common law coercive action, but doing so perpetuates the anomalies and rigidities of the "well-pleaded" rule. Professor Mishkin supported the result in Skelly, and minimized Justice Frankfurter's fears of a "vast current of litigation," by arguing that, pleading aside, plaintiff's claim in Skelly did not arise "directly" under federal law. The controversy did not arise "directly" because, in all cases where a private contract chooses an event measured by federal law, it was "state law under which the contract was made and would be enforced." Professor Mishkin concluded that the case fell outside original federal

75177 U.S. 505 (1900).

76241 U.S. 257 (1916).

77255 U.S. 180 (1921).

78339 U.S. 667 (1950).

79 Mishkin 177-84. 
question jurisdiction, just as would a claim based on a wager as to the next incumbent of a federal office. ${ }^{80}$

Professor Mishkin's analysis of the reason the claim in Skelly did not arise "directly" under federal law seems to boil down to no more than a sophisticated version of the proposition that it was state law which created the cause of action. I would prefer a different explanation. In cases like Skelly, arguably there is some need for an expert federal forum in interpreting federal law, even though that law has been incorporated in a private contract. But, obviously, that need is counterbalanced. First, there is the real possibility that the contract may be construed, once the merits of the controversy are reached, to render the issue of federal law irrelevant or inconclusive; there was in Skelly a real question whether the contract used the term "certificate of public convenience and necessity" in the same sense the Natural Gas Act used the term for entirely different purposes. ${ }^{81}$ Second, in most cases where issues of federal law are relevant only because incorporated in a private contract, there will be little federal interest in providing the protective jurisdiction of a sympathetic federal forum. And, finally, there would be real reason to fear a "vast current of litigation" in the federal courts if parties could, in effect, specify federal court jurisdiction by privately agreeing that their disputes would be governed by federal law. There may be some cases in which federal law is relevant only as incorporated in a private contract, and in which there would be sufficient federal interest to justify a conclusion favoring federal question jurisdiction. Arguably Skelly itself might be such a case. ${ }^{82}$ But a general rule applied to all cases in which federal law is incorporated in private contracts will work well in most cases, and provide an administrable and predictable standard for that group of cases. For that reason, I agree with Professor Mishkin that controversies as to the meaning of contractual terms incorporating federal standards do not arise directly under federal law. I disagree that the result can be explained entirely by inquiring what law created the cause of action or under what law "the contract was made and would be enforced."

As has been noted, the various irreconcilable formulae for measuring federal jurisdiction have a tendency to survive. In part,

$80 \mathrm{Id}$. at 183-84.

81339 U.S. at 678-79.

82 The Federal Power Commission would be indifferent neither to judicial construction of the scope of its order, nor to the question of whether its licensee had an assured supply of gas. As pointed out by $\mathrm{Mr}$. Justice Frankfurter, the litigation involved "determination of an important problem concerning a regulatory statute with implications of public importance that private litigants naturally enough do not wholly represent ...." For that reason, he suggested it might be appropriate for the trial court to have the "benefit of the experience and illumination" of the Federal Power Commission. Id. at 678 . 
this is because the courts understandably and properly have sought consistent results within groups of cases. Within limited groups of cases, a particular formula may describe the results. The "law that creates the cause of action" both describes and predicts results in cases where, like Skelly, federal law simply measures the terms of a private contract. It also works in some other classes of cases. A recurring situation is the personal injury action where a federal law standard is used to demonstrate that defendant's conduct amounted to wrongdoing. The plaintiff sues for damages for negligently-inflicted personal injuries and claims that the defendant's conduct was wrongful because it violated a federal statutory standard such as the Safety Appliance Act or the Civil Aeronautics Act. In these cases, the issue of federal question jurisdiction uniformly turns on the question whether federal or state law creates the cause of action. The case does not arise under federal law if federal law merely provides a standard of conduct which affects a state-law-based negligence action. In Moore v. Chesapeake \& $O . R y .{ }^{83}$ for example, plaintiff was a railroad employee engaged in intrastate commerce who sought recovery under a state compensation law. That law, in turn, removed the defenses of contributory negligence and assumption of risk if the accident was caused by violation of any law, state or federal, enacted for the safety of employees. Plaintiff claimed his employer had violated provisions of the Federal Safety Appliance Act. The Court held that the claim did not arise under federal law since the right to recover damages "sprang from the principle of the common law" 84 - even though interpretations of the Safety Appliance Act in the state courts were federal questions which could be reviewed by the Supreme Court. ${ }^{85}$ By way of contrast, however, if a federal law is construed to give a civil cause of action for wrongful conduct in violation of federal law, the case does arise under federal law. ${ }^{86}$ In personal injury cases then, the question of whether the case arises under federal law is uniformly decided by reference to the question whether federal law gives an express or implied cause of action, or whether federal law merely sets a standard of conduct for a state cause of action. ${ }^{87}$

Formulas such as "the law that creates the cause of action" continue because they do have limited utility. At the same time, they tend to obscure the pragmatic considerations which may govern de-

83291 U.S. 205 (1934).

$84 I d$, at 215 .

$85 I d$. at 214.

86 Fitzgerald v. Pan Am. World Airways, 229 F.2d 499 (2d Cir. 1956).

87 See, e.g., Moungey v. Brandt, 250 F. Supp. 445 (W.D. Wis. 1966) ; Moody v. McDaniel, 190 F. Supp. 24 (N.D. Miss. 1960); Mozingo v. Consolidated Constr. Co., 171 F. Supp. 396 (E.D. Va. 1959). 
cisions in the classes of cases for which the formulas are valid. In the personal injury cases just described, turning the jurisdictional issue on the question whether federal or state law gives the cause of action can be explained pragmatically. Many federal judges have been unhappy with the heavy load of personal injury cases swept into federal courts as the largest single component of diversity jurisdiction. It is true that there is some need for an expert federal forum to decide federal law issues in cases such as Moore $v$. Chesapeake $\&$ $O$. $R \mathrm{y}$. This need, however, must be balanced against the significant addition to the federal courts' caseload which would follow announcement of a principle which admitted personal injury actions because the defendant's wrongful conduct resulted, in part, from violation of one of a growing number of federal laws regulating individual conduct. ${ }^{88}$ It was to be expected that, in view of this balance, federal judges would not admit personal injury cases into the original jurisdiction of the district courts, unless they contained something more than federal law used to measure the wrongfulness of the defendant's conduct. Does the conclusion that federal law provides not only a rule of conduct but also a federal cause of action supply that "something more"? It does in the sense that a decision that federal law provides the cause of action represents a judgment by Congress, or by the courts, of the necessity for a protective federal forum for civil cases as well as a body of law regulating conduct. Moreover, once it is decided that federal law provides the cause of action, there are significant consequences beyond the decision that the case arises under federal law. Other issues, such as the appropriate defenses and measures of damages, become controlled by federal law. In cases where the plaintiff elects to proceed in a state court, state procedural law must yield when it is found to interfere unduly with enforcement of the federal right. ${ }^{89}$ In other words, the need for an expert and sympathetic federal forum increases significantly with the decision that federal law creates the cause of action. ${ }^{90}$

That "the law that creates the cause of action" works well for personal injury cases, does not mean that it should be viewed as a talismanic test of federal question jurisdiction for all tort cases. The recent case of Nationzeride Charters \& Conventions, Inc. v. Garber ${ }^{91}$

88 One example of federal safety standards which will be frequently involved in private personal injury litigation are those set by the Secretary of Transportation under the National Traffic and Motor Vehicle Safety Act. See Note, 80 Harv. I. REv. 688, 692-94 (1967).

89 See, e.g., Arnold v. Panhandle \& S.F.R., 353 U.S. 360 (1957).

90 And, of course, where the matter is in doubt, the need for a sympathetic federal forum influences the decision that federal law creates the cause of action. See generally Mishkin, The Varionsness of "Federal Iaw": Competence and Discretion int the Choice of National and State Rules for Decision, 105 U. PA. L. REv. 797 (1957).

01254 F. Supp. 85 (D. Mass. 1966). 
presents a good illustration. Northeast Airlines had brought suit in federal court to enjoin plaintiff from engaging in unauthorized air transportation in violation of the Federal Aviation Act. A final decree enjoining Nationwide Charters had been issued, although, due to two appeals, that judgment had not been settled at the time of this suit. In the instant case, Nationwide Charters sued in a state court for the tort of abuse of process in encouraging Northeast Airlines to bring the earlier suit. After defendant removed to federal district court, plaintiff moved to remand on the ground that the case did not arise under federal law. Plaintiff argued that the claim for abuse of the process of a federal court is a common law tort. In denying the motion, the district court concluded that the claim was "governed by federal law," although it was not necessary to "spell out what that law is." ${ }^{22}$ That conclusion was, in turn, rested on the interest of federal courts "not only in protecting their process but also in having such protection administered uniformly," ${ }^{93}$ - a kind of reverse-twist "protective jurisdiction." In Nationwide Charters it made good sense to recognize the existence of federal question jurisdiction to protect the successful party in a federal action, or those allied with him, from unnecessary harassment in the state courts. It ought not to have been necessary to conclude that the cause of action for malicious prosecution is federal in all respects to reach that result. ${ }^{94}$ But it is clear that the conclusion that federal law "governed" the claim was based on those pragmatic factors which ought to govern federal question jurisdiction. Frank recognition of those factors in other cases would go far toward rationalizing what has been a confusing issue.

The truth that finally emerges from Gully v. First National $B a n k^{95}$ is not that there are degrees by which federal law is "collateral, peripheral or remote," subject to precise or scientific measurement. No self-applying analytical standard will encompass the wide variety of cases where judgment on the limits of federal question jurisdiction is sought. As in the law of causation in torts, to which Justice Cardozo made analogy, the final decisional process lies in the "common sense accommodation of judgment to kaleidoscopic situations." 96

$82 I d$. at 86 .

$83 \mathrm{Id}$. at 87 .

94 Compare the rule that a suit on a federal court judgment does not arise under federal law. Metcalf v. Watertown, 128 U.S. 586 (1888). The practical import of that rule, however, has been minimized by the provision for registration of federal court judgments. 28 U.S.C. $\$ 1963$ (1964).

จ5 299 U.S. 109 (1936).

96299 U.S. at 117. Cardozo sought the answer to a causation question in an analytical formula in Palsgraf v. Iong Island R.R., 248 N.Y. 339, 162 N.E. 99 (1928). Judge Andrews protested that the problem could not be solved by any one consideration. Id. at 353-54, 162 N.E. at 104. Dean Prosser concluded in 1953 that the cases 


\section{Peripheral Applications of the Gully Standard}

That there is no magic in the "jurisdictional philosophy" of the Gully case also means that it has limited utility in solving problems other than defining the scope of the statutory grant of federal question jurisdiction. Mr. Justice Frankfurter, particularly, fell into the error of seeing in the Gully case a skeleton key which would unlock many dark federal jurisdiction closets. The most obvious mistake took place in Kesler $v$. Department of Public Safety ${ }^{97}$ where Mr. Justice Frankfurter's opinion for the Court attempted to use "the general principle elucidated by $\mathrm{Mr}$. Justice Cardozo in differentiating between different stages of adjudication at which issues are reached . . ." 98 to solve an issue concerning jurisdiction of a three-judge court. The question was whether suits to enjoin the enforcement of state statutes on the ground that they had been pre-empted by federal law could be handled by a single district judge, or required a special three-judge court. That question, in turn, was dependent upon whether an attack on a state statute on the basis of pre-emption was a suit for injunction "upon the ground of the unconstitutionality" of the state statute. 99 Mr. Justice Frankfurter attempted to reconcile earlier, confusing, decisions by having the issue of a three-judge court's jurisdiction in pre-emption suits depend on whether the Constitution was "immediately" or only "indirectly" brought into question. Kesler was overruled three years later, ${ }^{100}$ largely because it turned the three-judge court's jurisdiction on an issue that proved both "elusive" and "unworkable." 101 It also was overruled because the extent to which preliminary questions of statutory interpretation were raised had nothing to do with any of the reasons for invoking a three-judge court. ${ }^{102}$

Mr. Justice Frankfurter's dissent in Textile Workers Union v. Lincoln Mills ${ }^{103}$ had a more ambitious assignment for "the jurisdictional philosophy of Gully v. First National Bank." ${ }^{104}$ The question addressed by the Lincoln Mills dissent was the same as that in the

since Palsgraf demonstrate that "duty in negligence cases is a very involved and complex problem, in which many factors interplay, and that the opinion of Cardozo greatly over-simplified the whole matter." Prosser, Palsgraf Revisited, 52 MICr. L. REv. 1, 10 (1953).

97369 U.S. 153 (1962).

$98 \mathrm{Id}$. at 158. Justice Frankfurter had relied upon the Gully case, in passing, in Phillips v. United States, 312 U.S. 246, 253 (1941).

9928 U.S.C. \$2281 (1964).

100 Swift \& Co. v. Wickham, 382 U.S. 111 (1965).

101 Id. at $116,124$.

102 Id. at 128.

103353 U.S. 448,460 (1957).

104 Id. at 481 . 
Osborn case-the extent of Congress' power to create federal question jurisdiction with only a minimum of substantive federal law content. That question is beyond the scope of this article. The debate between Justice Frankfurter's Lincoln Mills dissent and Professor Mishkin ${ }^{105}$ comprehensively summarizes the arguments for a narrow or broad conception of Congress' power to enlarge federal question jurisdiction. It may be that Mr. Justice Frankfurter invoked the Gully case only for the proposition that there is some possible middle ground between Chief Justice Marshall's potential federal question test in Osborn and Justice Johnson's insistence on an actual federal question. ${ }^{106}$ It would be difficult to justify any further reliance on Gully in plumbing the limits of Congressional power to create federal question jurisdiction. The cases which have construed the statutory grant of federal question jurisdiction are of uncertain value when defining Congressional power to extend the jurisdiction in particular cases. The pragmatic considerations which should be considered in judging the constitutional question are not the same as those which focus on construing the general statutory grant of jurisdiction. The "jurisdictional philosophy of Gully v. First National Bank" tells us no more than that a pragmatic stopping place has to be located somewhere. Without more, that philosophy does not teach us how to draw the line.

\section{Summary}

Before a case can be said to "arise" under federal law, two distinct criteria must be fulfilled. The first criterion is that the issue of federal law be "well-pleaded" in the complaint. This is an arbitrary and capricious standard, which often turns on pleading rules which have lost all other significance under modern procedure. The "well-pleaded" requirement will not yield to good, pragmatic reasons for rejecting it in individual cases or groups of cases. ${ }^{107}$ That is because its sole justification is to provide a rule of thumb permitting the determination of jurisdiction on the face of the complaint. The capricious results ordained by the "well-pleaded" rule might be changed in several ways. At least in cases properly within the scope of the Declaratory Judgment Act, it would have been possible to permit a

105 Mishkin 184-96.

${ }_{106} \mathrm{Mr}$. Justice Frankfurter cites the Gully case to criticize Marshall's premise that every case in which a federal question might arise is capable of being commenced in a federal court. 353 U.S. at 481 .

107 On this point, Serio v. Liss, 300 F.2d 386 (3d Cir. 1961), is wrong.

The president of a local union sued for an injunction against his dismissal, and a declaratory judgment that the Landrum-Griffin Act did not justify his dismissal. The Court dispensed with the requirement that the federal issue be "well-pleaded" in the complaint because of the kinds of policy factors here articulated. See Note, 10 U.C.L.A.L. REv. 221, 224 (1962). 
potential defendant to raise a federal law issue in his declaratory judgment complaint. As of now, that solution seems to be foreclosed by Skelly Oil Co. v. Phillips Petroleum Co. ${ }^{108}$ More comprehensive reforms could involve, as suggested by the American Law Institute's Study of the Division of Jurisdiction Between State and Federal Courts, enlarging the opportunity for removal on the basis of a federal defense. ${ }^{109}$ Any such reforms, however, would increase the need for study of the second criterion of federal question jurisdiction, the requirement that a case arise directly under federal law. Unlike the "well-pleaded" rule, this requirement is not a rule of thumb, but a pragmatic limit upon federal question jurisdiction. Establishing the contours of that limit requires inquiries and guesses about such matters as these: the extent of the caseload increase for federal trial courts if jurisdiction is recognized; the extent to which cases of this class will, in practice, turn on issues of state or federal law; the extent of the necessity for an expert federal tribunal to handle issues of federal law that do arise; the extent of the necessity for a sympathetic federal tribunal in cases of this class. If the criteria of the "wellpleaded" rule are eliminated ot softened, much more thought will be necessary concerning the considerations which determine when issues of federal law make a case appropriate for initial federal trial.

108339 U.S. 667 (1950). Professor Mishkin argues that Justice Frankfurter's rationale in $S k e l l y$ is dicta, because plaintiff's claim did not arise directly under federal law. Mishkin 183-84.

109 ALI Study of the Drvision of Jurisdiction Between State and Federal CoUrTs $\$ 1312$ (Tent. Draft No. 4, 1966). 